\title{
FLATS' PRICES INDEXES ON THE SECONDARY MARKET IN POZNAŃ DURING 1996-2006
}

\section{Radosław Trojanek}

\begin{abstract}
The main aim of the paper was identification of price changes on the secondary flat market during 1996-2006 in Poznan. The subject scope resulted from the aim of the paper and included price fluctuations on the secondary flat market, involving both property rights and cooperative property rights for private accommodation. The time scope involved the period of 1996-2006, which was connected with the scope of empirical research which concerned shaping the price level of $1 \mathrm{~m}^{2}$ of flat. Flat prices indexes per square metre in Poznan were constructed with a mix-adjustment method. From theoretical point of view the aim of this method is to define the pure change flat price. The data on asking prices used to construct flat price indexes were published in weekly magazine, "Kup Dom" in the years 1996-2006. As a result of methodological processes (repeated sales offers were omitted - this phenomenon of repeated offers was caused by reporting them to more than one agency.) the quantity of base data decreased half as much and amounted to 51000. The number of collected offers in Poznan satisfies the condition of representative sample.
\end{abstract}

Keywords: housing market, house price indexes 